\title{
UJI EFEKTIFITAS EKSTRAK SIWAK (Salvadora Persica) BERBAGAI KONSENTRASI TERHADAP PEMBENTUKAN PLAK GIGI - Studi terhadap Murid MTsN Sale
}

\author{
Ervina Diah Ruslinawati*, Rahmawati Sri Praptiningsih**, Siti Chumaeroh**
}

\begin{tabular}{|c|c|}
\hline & ABSTRACT \\
\hline $\begin{array}{l}\text { Keywords: } \\
\text { miswak extract, } \\
\text { chlorhexidin, } \\
\text { plaque index }\end{array}$ & $\begin{array}{l}\text { Background: Nowdays many people who care about the health switching } \\
\text { from chemical drugs to herbal medicine. There are many herbs that } \\
\text { used for health. One is miswak (Salvadora persica) are many benefits to } \\
\text { general health and dental health. Siwak can help inhibit dental plaque. }\end{array}$ \\
\hline & 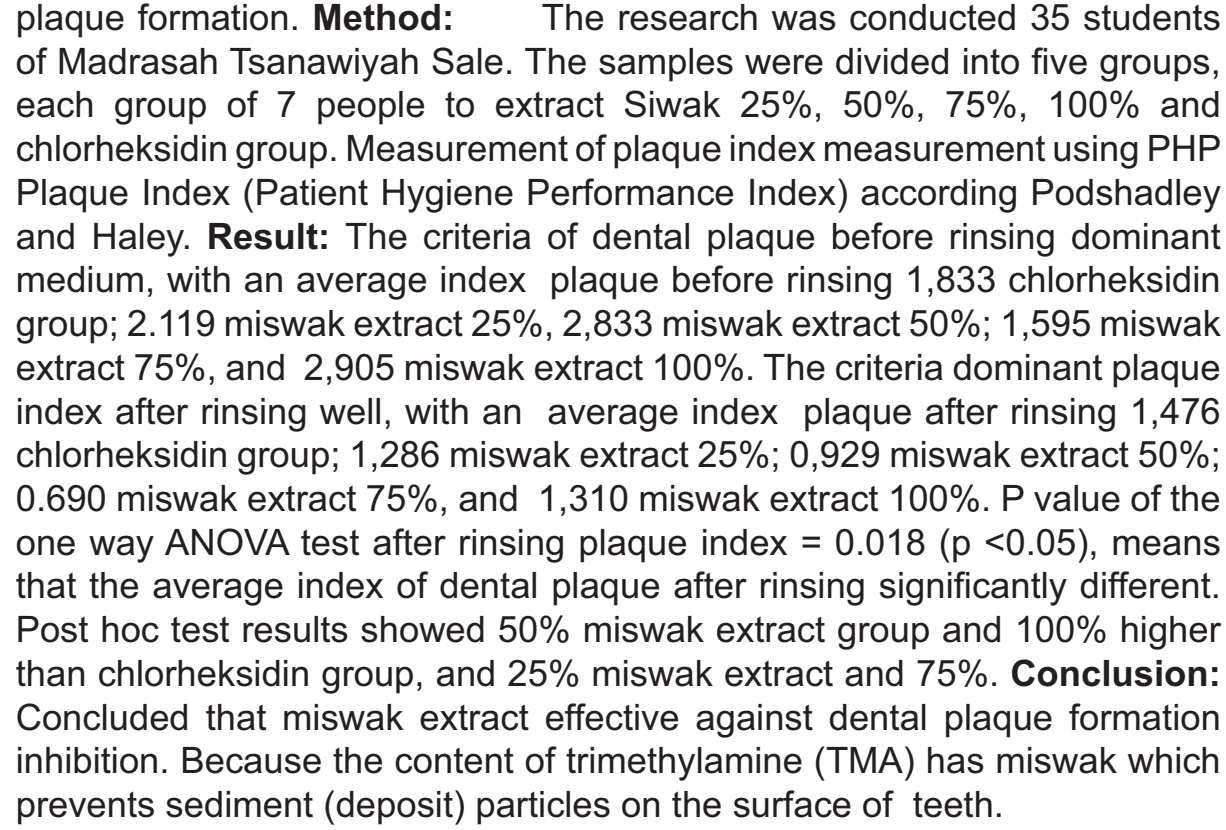 \\
\hline
\end{tabular}

\section{PENDAHULUAN}

Kesehatan rongga mulutmerupakan hal yang sangat penting, bahkan sejak zaman dahulu perhatian terhadap kesehatan gigi dan mulut sudah berlangsung di berbagai negara. Survei Kesehatan Rumah Tangga (SKRT) tahun 2001 yang dilakukan oleh Departemen Kesehatan RI, menunjukkan bahwa $71,2 \%$ penduduk diatas usia 10 tahun mengalami karies. Sedangkan untuk prevalensi karies usia 12 tahun sebesar $43,9 \%$, usia 15 tahun sebesar $37,4 \%$, dan meningkat pada usia 18 tahun menjadi $51,1 \%$. Hasil data tersebut ditunjang dengan meningkatnya prevalensi karies di Indonesia pada SKRT
2004 menjadi 90,05\% ${ }^{1}$.

Karies gigi merupakan multifactorial disease. Ada 4 faktor yang dapat menimbulkan karies, yaitu: host, mikroorganisme, substrat, dan waktu². Mikroorganisme (umumnya dari golongan Streptococcus mutans) yang merupakan salah satu etiologi dalam timbulnya karies banyak terdapat dalam plak gigi. Plak gigi adalah suatu lapisan putih kekuningan yang melekat pada bagian bukal, lingual dan bagian interproksimal gigi. Semakin rendah indeks plak maka akan semakin baik status oral higiene seseorang ${ }^{3}$.

Plak gigi dapat di kontrol menggunakan sikat gigi dan obat kumur. Obat kumur yang beredar di pasaran biasanya mempunyai

${ }^{*}$ Program Pendidikan Dokter Gigi UNISSULA, ${ }^{* *} F K G$ Universitas Islam Sultan Agung

Korespondesi: Ervina Diah Ruslinawati (ervinahanditya15@gmail.com) 
efek samping untuk rongga mulut jika pemakaiannya berlebihan. Oleh karena itu kita dapat memanfaatkan tanaman herbal sebagai obat kumur yang efektif dan mempunyai efek samping minimal untuk rongga mulut, salah satunya adalah Siwak (Salvadora persica).

Siwak (Salvadora persica) mempunyai kandungan yang sangat beragam dan bermanfaat bagi rongga mulut. Banyak penelitian telah dilakukan untuk mengetahui kelebihan dan manfaat dari batang siwak. Salvadora persica mengandung trimethylamine, salvadorine, chloride, fluoride, silica, sulphur, minyak mustard, vitamin C, resins dan tannin, saponirs, flavonoids, dan sterol. Salah satu kandungan siwak (Salvadora persica) yang berguna untuk mencegah terjadinya plak gigi adalah trimetilamin (TMA), zat ini mudah larut dalam air dan berfungsi sebagai zat apung (floatation agent) sehingga mampu mencegah endapan (deposit) partikel dan sisa-sisa makanan di rongga mulut khususnya di ruang antar gigi. Selain itu juga potensial sebagai antibakteri ${ }^{4}$.

Tujuan dari penelitian ini adalah untuk mengetahui efektifitas pemberian ekstrak siwak konsentrasi $25 \%, 50 \%, 75 \%$, dan $100 \%$ terhadap pembentukan plak gigi pada murid MTsN Sale.

\section{METODE PENELITIAN}

Penelitian ini merupakan jenis penelitian eksperimental atau uji klinis dengan menggunakan rancangan pre and post test with control group design untuk mengetahui pengaruh pemberian ekstrak siwak 25\%, 50\%, 75\%, dan 100\% terhadap pembentukan plak gigi.

Ekstrak siwak yang digunakan merupakan ekstrak yang dibuat dari ekstrak batang siwak yang diekstraksi dengan metode soxhletasi menggunakan pelarut ethanol $96 \%$. Hasil ekstrak yang diperoleh diuapkan pelarutnya dengan alat elektromanthel, kemudian dibuat konsentrasi $25 \%, 50 \%, 75 \%$, dan $100 \%$ melalui pengenceran dengan aquades. Larutan ini dibuat di Laboratorium Kimia Organik jurusan Kimia Fakultas MIPA Universitas Negeri Semarang.

Indeks plak adalah suatu angka, ukuran atau metode pengukuran luas dari permukaan gigi yang ditutupi oleh plak maupun kalkulus ${ }^{5}$.

Analisa hasil pengolahan data dilakukan dengan bantuan komputer menggunakan program SPSS 17.00 for windows. Untuk analisa data indeks plak maka dilakukan analisis parametrik dengan menggunakan analisis varians one way ANOVA dilanjutkan uji beda menggunakan uji Post Hoc. Sebelum dilakukan uji parametrik dilakukan uji normalitas, yang digunakan adalah uji Shapiro-wilk dan uji homogenitas, yang digunakan adalah Uji Lavene's test. Jika distribusi data tidak normal maka menggunakan analisis parametrik Kruskal-Walls dilanjutkan uji beda Independent T Test.

\section{HASIL PENELITIAN}

Tabel 1 menunjukkan rata-rata indeks plak gigi sebelum berkumur dengan berbagai larutan obat kumur adalah

\begin{tabular}{lccc}
\hline \multirow{2}{*}{ Kelompok } & \multicolumn{2}{c}{ Indeks plak } & \multirow{2}{*}{ p-value } \\
\cline { 2 - 3 } & Sebelum & Sesudah & \\
\hline Chlorheksidin & 1,833 & 1,476 & 0,043 \\
Ekstrak siwak 25\% & 2,119 & 1,286 & 0,012 \\
Ekstrak siwak 50\% & 2,833 & 0,929 & 0,000 \\
Ekstrak siwak 75\% & 1,595 & 0,690 & 0,030 \\
Ekstrak siwak 100\% & 2,905 & 1,310 & 0,005 \\
& & & \\
\hline
\end{tabular}

Tabel 1 Rata-rata indeks plak gigi sebelum dan sesudah antar kelompok perlakuan 
lebih tinggi dibandingkan dengan ratarata indeks plak gigi sesudah berkumur dengan berbagai larutan obat kumur. Nilai $p$-value hasil uji paired sample t-test menunjukkan rata-rata indeks plak gigi sebelum dan sesudah berkumur antar berbagai kelompok larutan adalah bermakna ditunjukkan dengan nilai $p<0,05$. Uji Normalitas pada tabel 2 didapat nilai distribusi data normal pada masing-masing kelompok perlakuan, ditunjukkan dengan nilai $p>0,05$. Hasil uji homogenitas pada tabel 3 menunjukan angka signifikansi $0,233(p>0,05)$ sehingga nilai varian data homogen.

\begin{tabular}{cc}
\hline Kelompok Perlakuan & P \\
\hline Chlorheksidin & 0,665 \\
Siwak 25\% & 0,980 \\
Siwak $50 \%$ & 0,452 \\
Siwak $75 \%$ & 0,406 \\
Siwak 100\% & 0,610 \\
\hline
\end{tabular}

Tabel 2 Data hasil Uji Shapiro-wilk (Uji normalitas)

\begin{tabular}{cc}
\hline $\begin{array}{c}\text { Levene's Test for } \\
\text { Equality of variances } \\
\text { based on mean }\end{array}$ & $\mathbf{P}$ \\
\hline & 0,233 \\
\hline
\end{tabular}

Tabel 3 Data uji Levene's Test (Uji homogenitas)

\begin{tabular}{ccc}
\hline Kelompok & Df & P \\
\hline Antara kelompok & 4 & 0,018 \\
Dalam kelompok & 30 & \\
Total & 34 & \\
\hline
\end{tabular}

Tabel 4 Data hasil uji one way Anova

Berdasarkan tabel 4 diperoleh nilai $p$ $=0,018(p<0,05)$ sehingga disimpulkan terdapat perbedaan rata-rata selisih indeks plak sebelum dan sesudah berkumur antar kelompok perlakuan. Hasil uji statistik dengan uji One Way Anova yang telah dilakukan, menunjukkan rata-rata selisih indeks plak gigi yang dihasilkan oleh ekstrak siwak berbagai konsentrasi

\begin{tabular}{llcc}
\hline (I) kelompok & (J) kelompok & $\begin{array}{c}\text { Mean } \\
\text { Difference (I-J) }\end{array}$ & p \\
\hline Chlorheksidin & Siwak 25\% & $-0,48$ & 0,319 \\
Chlorheksidin & Siwak 50\% & $-1,55^{*}$ & 0,003 \\
Chlorheksidin & Siwak 75\% & $-0,55$ & 0,253 \\
Chlorheksidin & Siwak 100\% & $-1,24^{-}$ & 0,013 \\
Siwak 25\% & Siwak 50\% & $-1,07^{\circ}$ & 0,030 \\
Siwak 25\% & Siwak 75\% & $-0,07$ & 0,880 \\
Siwak 25\% & Siwak 100\% & $-0,76$ & 0,115 \\
Siwak 50\% & Siwak 75\% & $1,00^{*}$ & 0,042 \\
Siwak 50\% & Siwak 100\% & 0,31 & 0,515 \\
Siwak 75\% & Siwak 100\% & $-0,69$ & 0,152 \\
\hline
\end{tabular}

Tabel 5 Data hasil uji Post Hoc

memiliki perbedaan yang signifikan yang ditunjukkan dengan nilai $p<0,05$.

Hasil tabel 5 diperoleh bahwa pada selisih rata-rata indeks plak gigi sebelum dan sesudah berkumur antara kelompok chlorheksidin dengan kelompok ekstrak siwak konsentrasi 50\% menunjukkan perbedaan yang signifikan dengan nilai $p=0,003$ dan rata-rata indeks plak gigi sebelum dan sesudah berkumur antara kelompok chlorheksidin dengan kelompok ekstrak siwak konsentrasi 100\% menunjukkan perbedaan yang signifikan dengan nilai $p=0,013$. Rata-rata selisih indeks plak gigi sebelum dan sesudah berkumur ekstrak siwak 50\% dan 100\% adalah lebih tinggi jika dibandingkan dengan rata-rata selisih indeks plak gigi sebelum dan sesudah berkumur dengan larutan chlorheksidin. Hal ini menunjukkan bahwa ekstrak siwak konsentrasi 50\% dan $100 \%$ lebih baik dalam menurunkan indeks plak gigi jika dibandingkan dengan chlorheksidin.

Selisih rata-rata indeks plak gigi sebelum dan sesudah berkumur antara kelompok siwak konsentrasi $25 \%$ dengan 
$50 \%$ menunjukkan perbedaan yang signifikan, ditunjukkan dengan nilai $p=$ 0,030 . Rata-rata selisih indeks plak gigi sebelum dan sesudah berkumur ekstrak siwak konsentrasi $50 \%$ adalah lebih tinggi jika dibandingkan dengan ratarata selisih indeks plak gigi sebelum dan sesudah berkumur dengan ekstrak siwak konsentrasi $25 \%$. Hal ini menunjukkan bahwa ekstrak siwak konsentrasi 50\% lebih baik dalam menurunkan indeks plak gigi jika dibandingkan dengan ekstrak siwak konsentrasi $25 \%$.

Selisih rata-rata indeks plak gigi sebelum dan sesudah berkumur antara kelompok siwak konsentrasi $50 \%$ dengan $75 \%$ menunjukkan perbedaan yang signifikan, ditunjukkan dengan nilai $p=$ 0,042 . Rata-rata selisih indeks plak gigi sebelum dan sesudah berkumur ekstrak siwak konsentrasi $50 \%$ adalah lebih tinggi jika dibandingkan dengan ratarata selisih indeks plak gigi sebelum dan sesudah berkumur dengan ekstrak siwak konsentrasi $75 \%$. Hal ini menunjukkan bahwa ekstrak siwak konsentrasi 50\% lebih baik dalam menurunkan indeks plak gigi jika dibandingkan dengan ekstrak siwak konsentrasi $75 \%$.

\section{DISKUSI}

Dari hasil analisa tersebut menunjukkan bahwa berbagai konsentrasi ekstrak siwak (Salvadora persica) baik ekstrak siwak konsentrasi 25\%, 50\%, 75\%, maupun $100 \%$ telah memberikan aktivitas yang dapat meningkatkan daya hambat pembentukan plak gigi. Hal ini terjadi karena dalam ekstrak siwak terdapat silika, minyak esensial, tanin, trimethilamin, thiosianat, dan fluorida yang dapat berfungsi menghambat atau mencegah pembentukan plak6789 .

Hasil penelitian menunjukkan bahwa ekstrak siwak konsentrasi $50 \%$ adalah ekstrak yang paling efektif dalam menghambat pembentukan plak gigi dan efeknya bahkan lebih baik jika dibandingkan dengan kelompok ekstrak siwak konsetrasi $75 \%$ dan 100\% bahkan dengan chlorheksidin yang telah direkomendasikan sebagai obat kumur.

\section{KESIMPULAN}

Dari penelitian ini di simpulkan bahwa efektifitas pemberian ekstrak siwak konsentrasi $50 \%$, dan $100 \%$ berbeda dengan kelompok Clorhexidin 0,2\%; efektifitas pemberian ekstrak siwak konsentrasi $50 \%$ berbeda dengan kelompok ekstrak siwak konsentrasi 25\% dan $75 \%$ terhadap pembentukan plak gigi. Pemberian ekstrak siwak $50 \%$ paling efektif dalam menghambat terbentuknya plak gigi.

\section{DAFTAR PUSTAKA}

1. PDGI online. Meneropong Penyakit Melalui Gigi. (cited 2009 Feb 12). Available from:http:// www.pdgi-online.com/v2/index.php?option

2. Kidd, E. A. M. \& Joyston-Bechal, S., 1992. Dasar-Dasar Karies Penyakit dan Penanggulangannya. Jakarta: Penerbit Buku EGC : 2-4

3. Endarti, dkk., 2007. Manfaat Berkumur dengan Larutan Ekstrak Siwak (Salvadora Persica). Majalah Kedokteran Nusantara Volume 40:40

4. Suryani, L. \& Astuti, Y., 2007. Uji Kadar Hambatan Minimal Ekstrak Batang Siwak (Salvadora persica) terhadap Staphylococcus aureus secara In Vitro. Majalah Kedokteran Gigi. Vol. 7. No. $1: 7-12$

5. Putri, M.H., dkk., 2011. Ilmu Pencegahan Penyakit Jaringan Keras dan Jaringan Pendukung Gigi. Jakarta: EGC Penerbit Buku Kedokteran, 53-59, 91-100

6. Almas, K. \& Al-Bagieh, N. H., 1999. The Antimicrobial Effects of Bark and Pulp Extracts of Miswak, Salvadora Persica. Biomedical Letters $60: 71-75$

7. Almas, K., 2002. The Effect of Salvadora Persica Extract (Miswak) and Chlorahexidine Gluconate on Human Dentin: A SEM Study. The Journal of Contemporary Dental Practice, Volume 3, No. 3:3

8. Al-Bayaty, F.H., dkk., 2010. Effect of mouth wash extracted from Salvadora persica (Miswak) on dental plaque formation: A clinical trail. Journal of Medicinal Plants Research Vol. 4(14), :1446-1454. Diakses dari http://www. academicjournals.org/JMPR

9. Adriyati, P. \& Santoso, O., 2011. Pengaruh Pemberian Larutan Ekstrak Siwak (Salvadora persica) Terhadap Pembentukan Plak Gigi. (Karya Tulis Ilmiah). Semarang. Fakultas Kedokteran Universitas Diponegoro 